\title{
The Analysis of Character Education in Teaching Physical Education
}

\author{
A. Suherman \\ Faculty of Sport and Health Education \\ Universitas Pendidikan Indonesia \\ Bandung, Indonesia \\ adangsuherman@gmail.com
}

\begin{abstract}
The phenomenon of the low character of students demands the teacher to be able to integrate character education in every subject at school. The purpose of this study is to find out some factors supporting the integration of character education in physical education. This study was conducted through a survey technique to 40 primary schools and 69 elementary school physical education teacher in Bandung, west Java. Instruments used are Value Orientation Inventory (VOI), questionnaire and observation. Through statistical and qualitative analysis showed that the teachers' value orientation, school context, and teaching process procedure provide the teachers opportunities to integrate character education in teaching physical education. Results of this study recommend further study of the importance of making a hypothetical model of the integrated character education in teaching physical education.
\end{abstract}

Keywords-Character Education, Teaching Physical Education, Teachers Values Orientation

\section{INTRODUCTION}

The phenomenon of the low character of students in Indonesia leads the government through the department of education encourage the teachers to be able to integrate character education in each subject in school, without exception, on the subjects of physical and sport education [1]. It is not surprising that every teacher seeks to implement various strategies of character education implementation in the learning process in accordance with the characteristics of each subject area. The purpose of character education integration in each subject is expected to not only to improve learning outcomes but also to increase students character, assuming that the good character will make the good results.

The implementation of the integrated character education in physical education is practically done by teachers of physical education at schools [2], however it has no evidence yet. Previous study show that teacher value orientation $[3,4]$ and the school context [5] including learning facilities, students, and support from different Human resources influence the strategy of teaching physical education. In addition, different school environment contributes to the success of the learning process [5]. However, how the strategy of the implementation and the factors influence the implementation of the integrated character education in physical education, up to now remains unknown. This is a challenge for researchers to learn more about the opportunities and the strategy of the implementation of the integration of character education in physical education.

The present study aimed to examine the effects of teacher value orientation and the school context on the implementation strategy of the integration of character education in physical education. in detail, the present study examine 1) the effect of the teachers value orientation and school context on learning effectiveness in physical education and their implications on the strategy of implementation character education integrated in teaching physical education; 2) the general strategy in implementing character education integrated in teaching physical education

\section{METHODS}

This study was conducted through a survey method in 40 primary schools and 69 elementary school physical education teacher in Bandung, which was done in two stages, the first is area determination and the second is schools and teachers determination. The instrument used was a questionnaire of physical education teachers Value Orientation Inventory (VOI) $[6,7,5]$, Questionnaire about attitude and skills of students, as well as the observation infrastructure, the effectiveness of the process, and the general mechanisms learning process integration character education in physical education.

\section{III. FINDING AND DISCUSSION}

\section{A. Correlation between Value Orientation Inventory (VOI) and the effectiveness of physical education Learning Process.}

From table 1, the correlation between VOI and effectiveness of the learning process as seen that

- All VOI have low correlation with the effectiveness of the learning process in physical education, except VOI Sport;

- Almost all VOI are positively correlated with the effectiveness of the learning process in physical education, except VOI games and sports. There are two possible explanations for why it happened

- VOI that is owned by the teachers are in medium or low category, thus they are not significant $[4,8]$ 
- Sports and games negatively affect the effectiveness of learning. The stronger the value orientation of teachers has sport increasingly lower propensity learning effectiveness [5]. Thus it can be said that the VOI of physical education teachers is not directly related to the effectiveness of learning, which implies that the implementation of character education in physical education can be applied to materials and other value orientation, except on the material and value orientation games and sports conditions because they are negatively correlated with the effectiveness of the process teaching physical education (see, Table 1).Use either SI (MKS) or CGS as primary units. (SI units are encouraged.) English units may be used as secondary units (in parentheses). An exception would be the use of English units as identifiers in trade, such as "3.5-inch disk drive."

TABLE I. CORRELATION COEFFICIENT BETWEEN VOI AND EFFECTIVENESS OF PHYSICAL EDUCATION LEARNING PROCESS

\begin{tabular}{|c|c|c|c|}
\hline VOI & $\mathrm{r}$ & Sig. (2-tailed) & Ho \\
\hline Movement & .090 & .347 & Accepted \\
\hline Games & $\begin{array}{l}- \\
.158\end{array}$ & .097 & Accepted \\
\hline Sport & $\begin{array}{l}- \\
.203\end{array}$ & .032 & Accepted \\
\hline Fitness & .053 & .582 & Accepted \\
\hline $\begin{array}{l}\text { Learning } \\
\text { Process }\end{array}$ & .012 & .900 & Accepted \\
\hline $\begin{array}{l}\text { Self- } \\
\text { Actualization }\end{array}$ & .053 & .580 & Accepted \\
\hline $\begin{array}{l}\text { Ecological } \\
\text { Integration }\end{array}$ & .101 & .287 & Accepted \\
\hline $\begin{array}{l}\text { Social } \\
\text { Reconstruction }\end{array}$ & .040 & 679 & Accepted \\
\hline
\end{tabular}

\section{B. Correlation between school environment and the} effectiveness of physical education learning Process

From the table 2 the correlation between the school environment and the effectiveness of the learning process seem that all the items the school environment positively and significantly correlated with the effectiveness of the learning process of physical education. These results are consistent with some previous research [9]. External support which involves a series of principals, teachers of other subjects, and parents' supports on the physical education learning process has a very significant effect on the electivity of physical education learning.

TABLE II. CORRELATION COEFICIENT BETWEEN FACTOR AND LEARNING PROCESS

\begin{tabular}{llll}
\hline School Env & r & $\begin{array}{l}\text { Sig. } \\
\text { (2-tailed) }\end{array}$ & Ho \\
External Support & $.504^{* *}$ & .000 & Accepted \\
Learning Process of & $.396^{* *}$ & .000 & Accepted \\
Physical Education & & & \\
Students attitude & $.439^{* *}$ & .000 & Accepted \\
Students Skill & $.533^{* *}$ & .000 & Accepted \\
\hline
\end{tabular}

\section{General Mechanism of Character Education in Physical Education Learning Process Integration}

TABLE III. GENERAL MECHANISM OF CHARACTER EDUCATION IN PHYSICAL EDUCATION LEARNING PROCESS INTEGRATION

\begin{tabular}{|c|c|c|c|}
\hline & Structure & Traditional & Scientific \\
\hline \multirow{3}{*}{1} & & -Phisical Activity & -Phisical Activity \\
\hline & Introduction & -Discipline & -Discipline \\
\hline & \multirow{7}{*}{ Core } & -Explanation & -Explanation \\
\hline \multirow{6}{*}{2} & & & -Play \\
\hline & & -Skill & -Teach \\
\hline & & Explanation & understand \\
\hline & & -Skill Exercise & -Drill \\
\hline & & -Games & -Games \\
\hline & & & -Reflection \\
\hline
\end{tabular}

The tendency of the integrated character building is characterized by a tradition of physical education teachers delivered pollutes in participating the learning process. Contents of this pollutes can basically be classified into two behaviors, namely general consisting of personal and social behavior; as well as the specific behavior that essentially routine should be followed by students' at any time they participate the learning process of physical education both in the field and in the classroom [10,11]. Procedurally, a common mechanism of learning process of character integrated physical education above is good but not enough $[12,2]$ because it must be followed up and reflected in the behavior of teaching and the learning process, the core and the cover as well as done continuously and constantly in every teaching.

General mechanism of integrated character of physical education learning processes as revealed in the field tend to only be done at the beginning of the semester and presented in 
the introductory part of the learning process while the core process routine maintenance tend to be forgotten.

In physical education, warning or punishment during a lecture takes place frequently appears as a character building but this is often not the integrated circuit of pollutes given at the beginning of the learning process as well as its implementation is still not done regularly and planned. However, from the data on the general mechanism of learning process of the integrated character in physical education, we can conclude that the general mechanism of this character learning process gives a good opportunity for the implementation of the integration of character education in physical education.

\section{CONCLUSION AND RECOMMENDATIONS}

Character education is possible to be implemented in physical education without having to change the existing national curriculum materials, but only by adding and strengthening learning process structure that contains the message character in the introduction, the core and the closing. However, the school environment factors should be taken into consideration because these factors positively and significantly affect the effectiveness of teaching physical education. The further study needs to define a hypothetical model of the integrated character education of physical education.

\section{REFERENCES}

[1] Suherman, Adang, (2013), Membangun Kualitas Hidup Bangsa melalui Pendidikan Jasmani, Makalah Pidato Pengukuhan Guru Besar bidang Sport Pedagogy, Universitas Pendidikan Indonesia.

[2] Suherman, Adang, (2009a), Revitalisasi Pengajaran dalam pendidikan Jasmani, Cetakan Pertama, Penerbit: CV. Bintang WarliArtika, bandung, Indonesia

[3] Jewett, A.E. (1994). "Curriculum Theory and Research in Sport Pedagogy”. Sport Science Review. Sport Pedagogy. 3 (1). h. 11-18.

[4] Jewett, A.E., Bain, L., and Ennis, C. D. (1995) The Curriculum Process in Physical Education. Dubuque, IA: WMC Brown.

[5] Suherman, Adang, (2009b), Actual curriculum of physical education At elementary schools and its implication to the development of Teaching and curriculum, The International Journal of Asian Society for Physical Education and Sport (IJASPES), volume 7, no 2, 2009.

[6] Ennis, C. D. dan Hooper, L. M. (1988). "Development of An Instrument for Assessing Educational Value Orientations". Journal of Curriculum Studies. 20 (3).

[7] Ennis, C. D. dan Zhu, W. (1991). "Value Orientation: A Description of Teachers' Goals for Student Learning”. Research Quarterly for Exercise and Sport. 62 (1).

[8] Steinhard, M. A. (1992). "Physical Education", Handbook of Research on Curriculum, AERA. Austin, Texas: MacMillan Publishing Company.

[9] Suherman, Adang, (2010), Determinan Terhadap Kecenderungan Nilai Rujukan Guru Pendidikan Jasmani, Jurnal Ilmiah Pendidikan, November 2010, th XXIX, No.3. Penerbit Ikatan sarjana Pendidikan indonesia, DIY, bekerja sama dengan LPM UNY

[10] Siedentop, D. (1991). Developing Teaching Skills in Physical Education. California: Mayfield Publishing Company.

[11] Siedentop, D. (1994). Quality PE through Positive Sport Experiences: Sport Education. Illinois: Human Kinetics.

[12] Graham, G. (1992). Teaching Children Physical Education: Becoming a Master Teacher. Campaign, Illinois: Human Kinetics Publishers. 